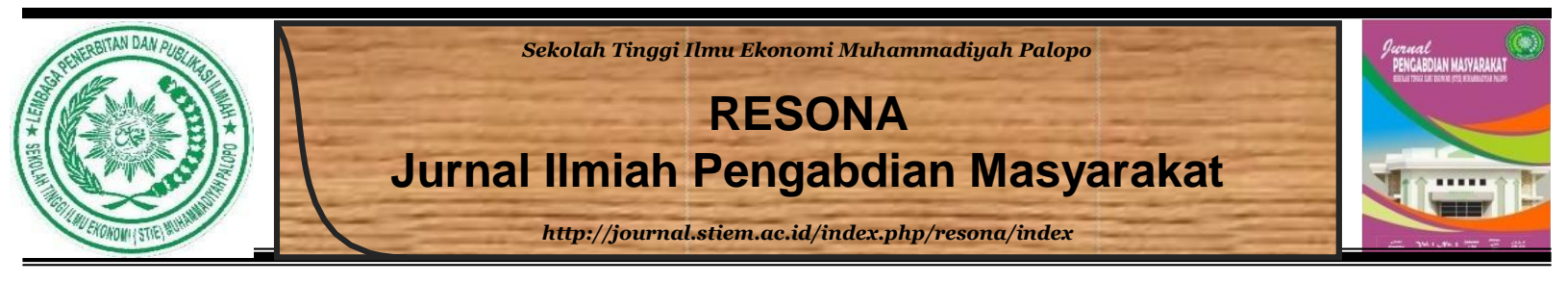

\title{
Pemberdayaan Masyarakat Melalui Pembuatan Kerupuk Gendar Sebagai Usaha Skala Rumahan Dalam Meningkatkan Kesejahteraan Di Desa Malangke Kec. Malangke Kab. Luwu Utara
}

\author{
1Indra Kusdarianto, ${ }^{2}$ Andi Nurul Mukhlisa
}

${ }^{1,2}$ STIE Muhammadiyah Palopo

\begin{tabular}{l} 
INFO NASKAH \\
\hline Diserahkan \\
10 maret 2018 \\
Diterima \\
21 mei 2018 \\
Diterima dan Disetujui \\
11 Juni 2018 \\
\hline
\end{tabular}

Kata Kunci:

Kerupuk Gendar, Usaha

Skala Rumahan

\begin{abstract}
ABSTRAK
Kuliah Kerja Lapang - Pembelajaran Pemberdayaan Masyarakat (KKNPPM) bertujuan untuk melaksanakan fungsi tridharma perguruan tinggi bagi setiap Dosen STIE Muhammadiyah Palopo. Salah satunya tridharma tersebut adalah melaksanakan pengabdian masyarakat dengan "Pemberdayaan Masyarakat Melalui Pembuatan Kerupuk Gendar Sebagai Usaha Skala Rumahan dalam Meningkatkan Kesejahteraan di Desa Malangke Kecamatan Malangke Kabupaten Luwu Utara". Permasalahan dalam pengabdian tersebut adalah (1) Usaha ini belum dikelola secara propesional sehingga krupuk gendar di masyarakat mulai terkikis oleh makanan modern,(2) Belum ada pembinaan dari intansi terkait, seperti pelatihan kewirausahaan tetang pengolaan kerupuk gendar sebagai usaha rumahan, (3) Masyarakat terkendala permodalan dan akses pemasaran. Metode pendekatan dalam program tersebut meliputi : (1) Peragaan, yaitu melalui presentasi dan demontrasi pembuatan krupuk gendar. (2) Pelatihan-Pelatihan kepada masyarakat tentang kewirausahaan, (3) Semua kegiatan program tersebut didampingi oleh tim pelaksana. Hasil yang dicapai dalam program KKNPPM adalah (1) Produk Kerupuk Gendar bentuk kemasan (2) Artikel ilmiah. Untuk lebih memudahkan pemahaman bagi masyarakat sasaran dilakukan praktek langsung dalam setiap tahapan pembuatan kerupuk gendar. Dari hasil peragaan tersebut masyarakat sasaran dapat menerapkan pengolaan kerupuk gendar sebagai usaha skala rumahan sehingga dapat meningkatkan perekonomian masyarakat di Desa Malangke Kecamaan Malangke Kabupaten Luwu Utara.
\end{abstract}




\section{Pendahuluan}

Desa Malangke Kecamatan Malangke Kabupaten Luwu Utara yang berjarak $\pm 91 \mathrm{~km}$ dari Kota Palopo. Desa Malangke terdiri dari 4 (empat) dusun, yaitu Dusun Babana Kawali, Dusun Malangke, Dusun Karya Baru, dan Dusun Birue Sementara jumlah penduduk Desa Malangke dengan 410 KK yaitu 1.767 jiwa, terdiri laki-laki 891 jiwa dan perempuan 876 jiwa (Sumber kantor desa Malangke, 2017)

Berdasarkan hasil dari pengamatan yang kami lakukan, bahwa secara umum potensi wilayah di desa Malangke Kecamatan Malangke Kabupaten Luwu Utara memiliki potensi di sektor pertanian dan perkebunan, salah satunya adalah tanaman padi yang menghasilkan beras. Beras tentu tidak asing bagi kita semua, beras adalah merupakan kebutuhan pokok bagi masyarakat Indonesia secara umum, tentu beras selalu ada dalam setiap harinya. Beras disamping untuk kebutuhan pokok juga bisa diolah menjadi beberapa jenis makanan lainnya, salah satunya adalah diolah menjadi kerupuk gendar yang bisa memberikan manfaat tambahan kalau diolah secara propesional. Kerupuk gendar bagi masyarakat luwu secara umum tentu sangat asing akan jenis makanan tersebut tetapi bagi masyarakat dikalangan orang jawa tentu tidaklah sangat asing. Kerupuk gendar merupakan jenis olahan dari warisan leluhur masyarakat jawa yang sekarang sudah punah karena terkikisnya perkembagan zaman oleh makanan-makanan olahan modern. Kerupuk gendar pada masa dahulu hampir dijumpai di seluruh masyarakat jawa pada saat hari raya keagamaan karena sebagai sajian utama dalam menyambut tamu yang datang dirumahnya. Kerupuk gendar punya rasa rencah dan agak asin bagus untuk camilan disaat sambil dikusi atau ngobrol dan lebih nikmat lagi dengan hidangan teh hangat atau kopi manis. Kerupuk gendar juga bisa dihidangkan saat makan siang atau makan malam sebagai camilan tambahan. Kerupuk gendar juga bisa dikembangan sebagai bisnis olahan rumahan, disamping menjaga makanan tradisional warisan leluhur juga bisa menambah income pendapatan bagi masyarakat.

Dengan melihat potensi yang dimiliki di desa Malangke disektor pertanian dan perkebunan, maka kami terpanggil untuk melakukan pengabdian masyarakat, dengan program Kuliah Kerja Nyata - Pembelajaran Pemberdayaan Masyarakat (KKN-PPM) tahun akademik 2018-2019, dengan melibatkan mahasiswa, beserta masyarakat setempat.

Salah satu program utama dalam kegiatan KKN-PPM ini adalah pemberdayaan masayarakat melalui pengolaan kerupuk gendar, meliputi berbagai kegiatan pelatihan kewirausahaan, dengan tujuan : 1) Meningkatkan peran wanita dalam rumah tangga agar berkontribusi melalui bisnis rumahahan sebagai income pendapatan. 2) Meningkatkan 
keterampilan bagi para ibu-ibu tentang pengolaan kerupuk gendar dalam bentuk produk. Sehingga dengan kegiatan tersebut maka sasaran yang hendak ingin di capai dalam program tersebut yaitu meningkatkan tarap hidup perekonomian masyarakat di Desa Malangke Kecamatan Malangke Kabupaten Luwu Utara dapat tercapai.

Pengabdian kepada masyarakat merupakan pelaksanaan pengamalan ilmu pengetahuan, teknlogi dan seni budaya langsung pada masyarakat secara kelembagaan melalui metodologi ilmiah sebagai penyebaran tridharma Perguruan Tinggi serta tanggung jawab yang luhur dalam usaha mengembangkan kemampuan masyarakat, sehingga dapat mempercepat lajut pertumbuhan tercapainya tujuan pembangunan nasional.

Dengan demikian, maka melalui program KKN-PPM ini, dengan tema "Pemberdayaan Masyarakat melalui Pembuatan Kerupuk gendar sebagai usaha skala rumahan dalam meningkatkan kesejahteraan di Desa Malangke Kecamatan Malangke Kabupaten Luwu Utara” dapat terlaksana, sehingga diharapkan perekonomian di Desa tersebut menjadi meningkat dan masyarakatnya lebih sejahtera.

\section{Masalah}

Berdasarkan latar belakang dari pontensi Desa Malangke Kecamatan Malangke Kabupaten Luwu Utara. Maka yang menjadi permasalahan dimasyarakat sebagai sasaran program pemberdayaan masyarakat melalui KKN-PPM, tersebut adalah :.

1. Usaha ini belum dikelola secara propesional, sehingga krupuk gendar di masyarakat mulai terkikis oleh makanan modern.

2. Belum ada pembinaan dari intansi terkait, seperti pelatihan kewirausahaan tetang pengolaan kerupuk gendar sebagai usaha rumahan.

3. Masyarakat terkendala permodalan dan akses pemasarannya. Dengan melihat permasalahan tersebut, maka melalui program KKN-PPM atau pemberdayaan masyarakat bisa memberikan solusi dan manfaat bagi masyarakat di desa Malangke Kecamatan Malangke Kabupaten Luwu Utara secara khusus dan program KKN-PPM diharapkan bisa berkelanjutan.

\section{Metode}

Dalam pelaksanaan kegiatan KKN-PPM tahun akademik 2018-2019 dilaksanakan di Desa Malangke Kecamatan Malangke Kabupaten Luwu Utara dimulai sejak tanggal 02 Juli 2018 sampai dengan 02 Agustus 2018. Dan dari uraian permasalahan yang dihadapi oleh masyarakat sebagai sasaran program pemberdayaan masyarakat melalui KKN-PPM adalah :. 
1. Usaha ini belum dikelola secara propesional, sehingga kerupuk gendar di masyarakat mulai terkikis oleh makanan modern.

2. Belum ada pembinaan dari intansi terkait, seperti pelatihan kewirausahaan tetang pengolaan kerupuk gendar sebagai usaha rumahan.

3. Masyarakat terkendala permodalan dan akses pemasarannya

Adapun metode yang digunakan dalam kegiatan program KKN-PPM tersebut pendekatannya adalah bersifat langsung, yaitu melalui :

1) Peragaan, yaitu melalui presentasi dan demontrasi pembuatan kerupuk gendar dengan menggunakan alat dan bahan peraga.

2) Pelatihan-pelatihan kepada kelompok masyarakat tentang pembuatan kerupuk gendar sampai pada pemasarannya..

3) Semua kegiatan program tersebut didamping oleh tim pelaksana
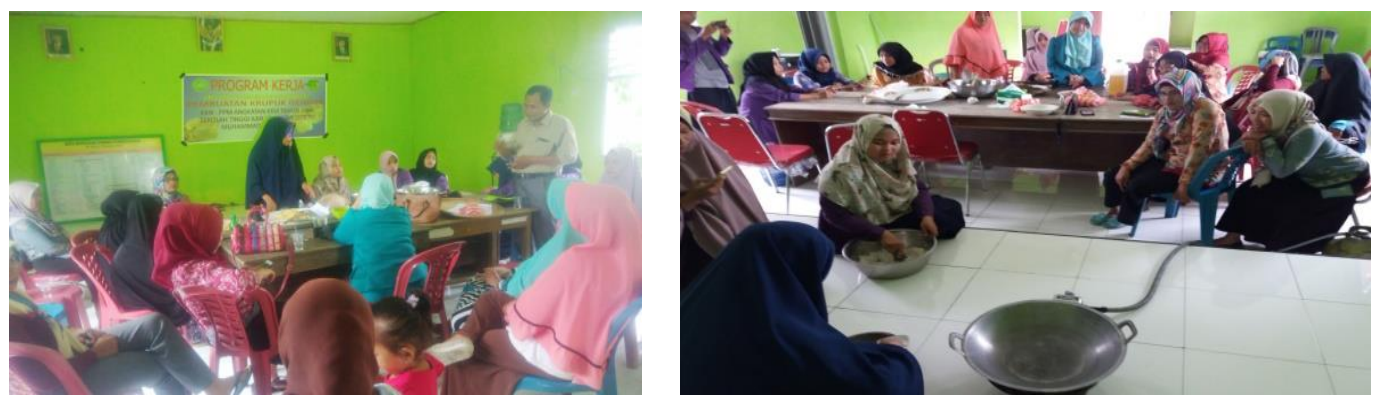

1. Pelatihan Pembuatan Kerupuk Gendar 2. Praktek Pembuatan Kerupuk Gendar

\section{Metode/Kebijakan/Konsep Yang Digunakan}

Adapun metode/kebijakan yang digunakan dalam pelaksanaan program kegiatan $\mathrm{KKN}$ PPM tersebut dapat digambarkan dalam bagan 2.1 sebagai berukut :

\section{Gambar 1: Skema Metode/Kebijakan/Konsep Yang Digunakan}

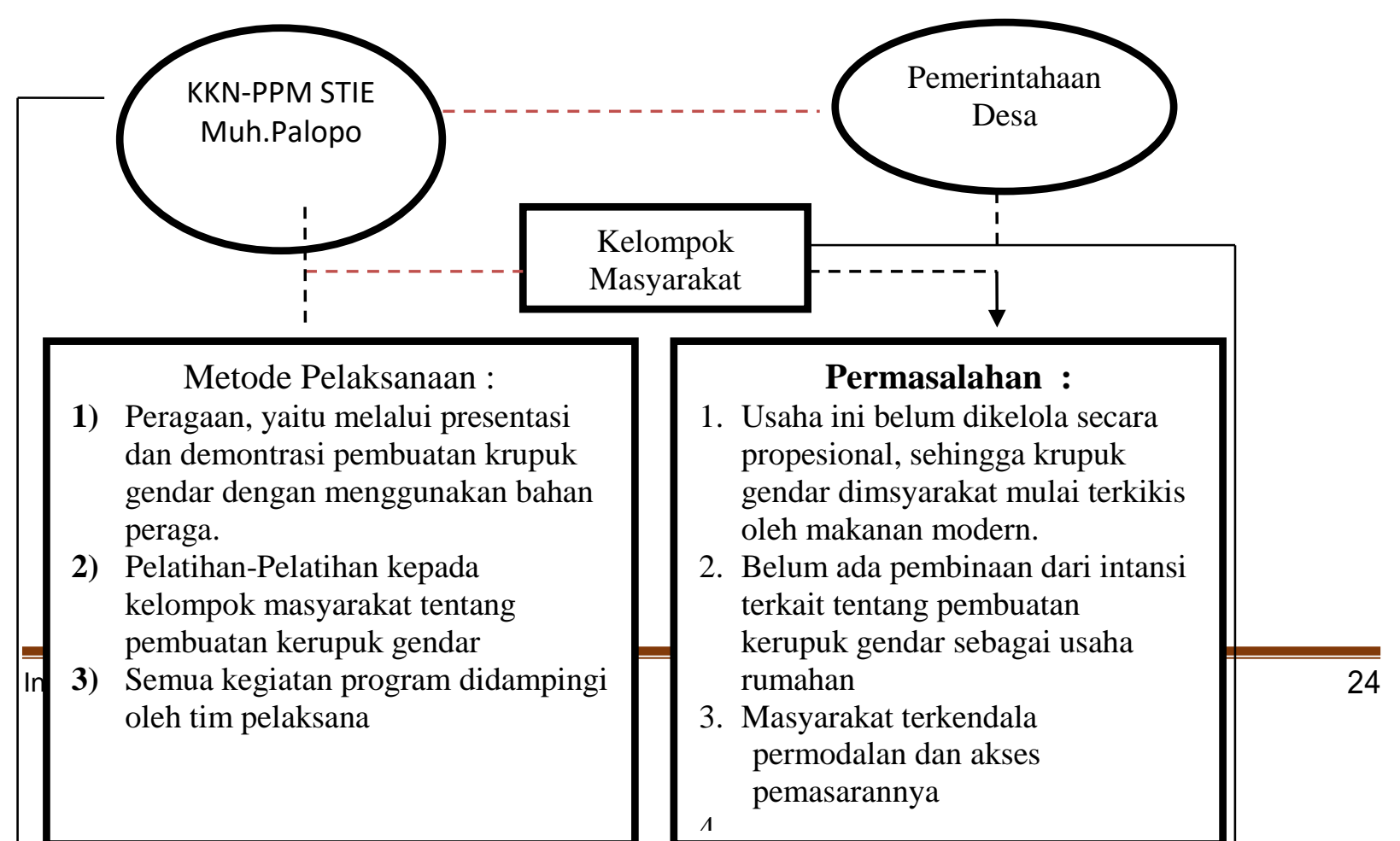




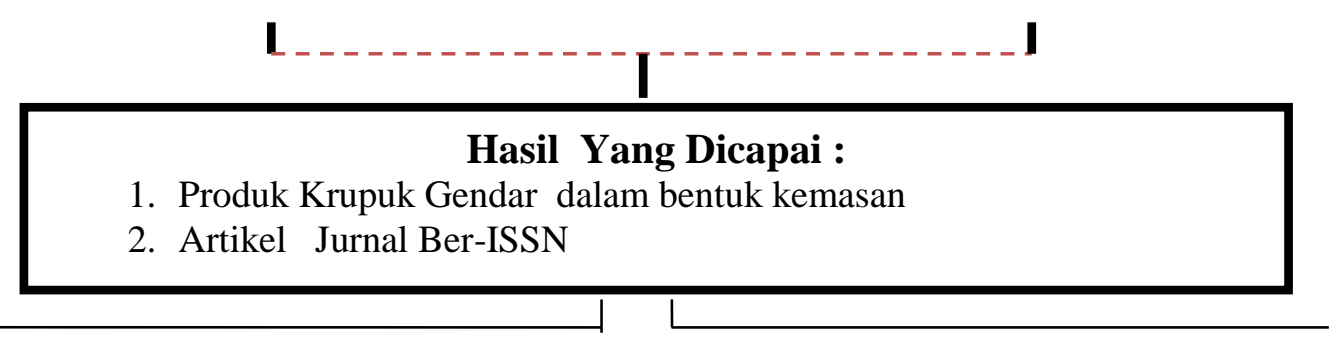

\section{Lemabaga Mitra Program KKN-PPM}

Untuk mencapai tujuan dari kegiatan program KKN-PPM tersebut, maka di perlukan kerja sama dari lembaga mitra yang sesuai dengan bidang yang akan dilaksanakan, yaitu pengolaan krupuk gendar. Hal ini dimaksudkan supaya kegiatan tersebut bisa berjalan dengan baik dan berkelanjutan.

Adapun kelompok mitra adalah kelompok masyarakat di Desa Malangke Kecamatan Malangke Kabupaten Luwu Utara. .Kemudian untuk memudahkan dalam pelaksanaan kegiatan program tersebut, kelompok masyarakat bersedia menyediakan tempat kegiatan. Selanjutnya bidang kegiatan yang dilaksanakan adalah pengolaan krupuk gendar sebagai usaha skala rumahan.

\section{Susunan Kelompok Sasaran}

Berdasarkan dari uraian permasalahan yang dihadapi oleh kelompok sasaran atau kelompok masyarakat, yaitu :.1) Usaha ini belum dikelola secara propesional, sehingga krupuk gendar menjadi puna. 2) Belum ada pembinaan dari intansi terkait melalui pelatihan kewirausahaan tetang kerupuk gendar sebagai usaha rumahan, (3) Sehingga kelompok masyarakat tersebut mengalami kendala-kendala dalam pengembangan usahanya tersbut. Maka selanjutnya yang menjadi kelompok sasaran pelaksanaan program KKN-PPM tersebut adalah masyarakat di Desa Malangke Kecamatan Malangke Kabupaten Luwu Utara dengan melakukan berbagai kegiatan pelatihan praktek kewirausahaan meliputi : 1) Praktek pengenalan teknologi/media kepada kelompok sasaran, 2) Praktek pembuatan krupuk gendar kepada kelompok sasaran, 3) Praktek pemasaran krupuk gendar kepada kelompok sasaran. 


\section{Hasil dan Pembahasan}

Adapun langkah-langkah dalam pelakasanaan program KKN-PPM yang diilaksanakan di Desa Malangke Kecamatan Malangke Kabupaten Luwu Utara dapat dilihat pada tabel 3.1 sebagai berikut :

\section{Tabel 1 : Langkah-langkah /Bentuk Program KKN-PPM}

\begin{tabular}{|c|c|c|}
\hline No & Nama Program & Bentuk Program \\
\hline \multirow[t]{6}{*}{1} & \multirow{6}{*}{$\begin{array}{l}\text { Perencanaan Program } \\
\text { KKN-PPM }\end{array}$} & a. Pembekalan Peserta Program KKN-PPM \\
\hline & & b. Rapat persiapan kerja \\
\hline & & c. Membuat time schedule kerja \\
\hline & & d. Membentuk Struktur kegiatan \\
\hline & & e. Membuat dapur umum \\
\hline & & f. Sosialisasi kemasyarakat \\
\hline 2 & Pengolaan data target & $\begin{array}{l}\text { Mengidetifikasi kondisi masyarakat (sumer } \\
\text { daya alam, sosial ekomomi, kultur) }\end{array}$ \\
\hline 3 & $\begin{array}{l}\text { Penetapan masalah dan } \\
\text { tujuan kegiatan }\end{array}$ & $\begin{array}{l}\text { Menentukan arah dan tujuan kegiatan KKN- } \\
\text { PPM }\end{array}$ \\
\hline \multirow[t]{2}{*}{4} & \multirow[t]{2}{*}{$\begin{array}{l}\text { Sosialisasi program KKN- } \\
\text { PPM }\end{array}$} & $\begin{array}{l}\text { a. Mengundang tomas, pemuda, tokoh agama, } \\
\text { dan pemerintah desa mengikuti seminar } \\
\text { program }\end{array}$ \\
\hline & & b.Seminar kegiatan kerja KKN-PPM \\
\hline \multirow[t]{2}{*}{5} & \multirow[t]{2}{*}{$\begin{array}{l}\text { Penyiapan peralatan dan } \\
\text { proses pengolaan kerupuk }\end{array}$} & $\begin{array}{l}\text { a. Pengadaan kebutuhan bahan pembuatan } \\
\text { kerupuk gendar }\end{array}$ \\
\hline & & b. Pengadaan alat penunjang \\
\hline \multirow[t]{4}{*}{6} & \multirow{4}{*}{ Pelatihan-Pelatihan } & a. Praktek kewirausahaan \\
\hline & & b. Praktek pengenalan media teknologi \\
\hline & & c. Paraktek pembuatan krupuk gendar \\
\hline & & d. Praktek Pemasaran produk \\
\hline \multirow[t]{4}{*}{8} & \multirow[t]{4}{*}{ Praktek Kerja } & a.Penyiapan bahan-bahan yang diolah \\
\hline & & $\begin{array}{l}\text { b. Pemilihan jenis-jenis bahan yang akan } \\
\text { diolah }\end{array}$ \\
\hline & & c. Pencampuran bahan-bahan \\
\hline & & d. Pemasakan bahan-bahan \\
\hline \multirow[t]{3}{*}{9} & \multirow[t]{3}{*}{ Praktek Kerja } & a. Pendinginan \\
\hline & & b. Penjemuran \\
\hline & & c. Penggorengan \\
\hline 10 & Pengepakan Produk & Pengepakan produk \\
\hline 11 & Praktek Kerja & Pemasaran Produk \\
\hline \multirow[t]{2}{*}{12} & \multirow{2}{*}{$\begin{array}{l}\text { Monitoring \& Evaluasi } \\
\text { kegiatan }\end{array}$} & a. Pendampingan dan pembimbingan \\
\hline & & b. Konsultasi (coaching klinik \\
\hline 13 & Seminar Hasil KKN-PPM & a. Penyusunan \& laporan hasil KKN-PPM \\
\hline
\end{tabular}


Resona Jurnal Ilmiah Pengabdian Masyarakat, (2018)

\section{Proses Pembuatan Kerupuk Gendar}

b. Seminar hasil KKN-PPM

\section{a. Bahan-Bahan Dasar}

Adapun bahan-bahan yang dibutuhkan dalam pembuatan kerupuk gendar yaitu :

1) Loyang/wajan

2) pisau

3) Sodek

4) Tepuk Tapioka secukupnya

5) Nasi secukupnya

6) Plastik

7) Garam secukupnya

8) Bubu kaldu secukupnya

9) Minyak goreng secukupnya

\section{b. Proses Pembuatan Kerupuk Gendar}

Setelah bahan semua sudah siap dalam pembuatan kerupuk gendar, maka :

1) Tuangkan air mendidih kedalam tepung tapioka lalu aduk hingga mengental

2) Masukan adonan dalam nasi hangat tambahkan bumbu halus, garam dan kaldu bubuk.

Selanjutnya tumbuk nasik tersebut supaya hancur.

3) Siapkan loyang yang di olesi minyak goreng kemudian alasi plastik supaya tidak lengket . Tuangkan adonan nasi ke dalam loyang, ratakan dan padatkan. Selanjutnya kukus sampai matang ( 30 menit)

4) Angkat dan dinginkan kreupuk yang dikukus

5) Potong-potong kerupuk yang sudah di dinginkan sesuai selera dan jemur hingga kering

6) Kerupuk siap digoreng atau di simpan.

\section{c. Produk Kerupuk Gendar}

Adapun yang menjadi output pada program KKN-PPM tersebut adalah berupa produk kerupuk gendar, adalah sebagai berikut :

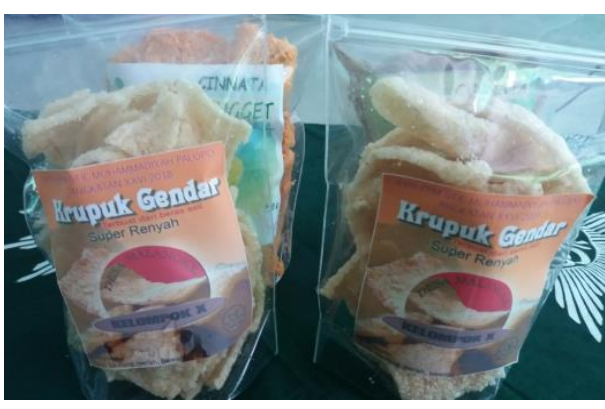

1. Kerupuk Gendar dlm Kemasan

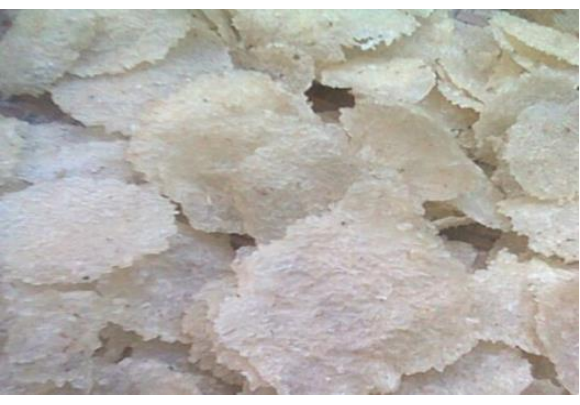

2. Kerupuk gendar belum digoreng 


\section{Rencana Keberlanjutan Program}

Rencana keberlanjutan Program KKN-PPM yang melibatkan masyarakat di Desa Malangke Kecamatan Malangke Kabupaten Luwu Utara dengan tema "Pemberdayaan Masyarakat Melalui Pembuatan Kerupuk Gendar Sebagai Usaha Skala Rumahan Dalam Meningkatkan Kesejahteraann Masyarakat di Desa Malangke Kecamatan Malangke Kabupaten Luwu Utara." diharapkan memiliki prospek yang baik dimasa yang akan datang dan bisa memberikan manfaat bagi perekonomian masyarakat di Desa Malangke, khususnya dan daerah Luwu Utara pada umumnya. Sehingga program KKN-PPM tersebut akan berkelanjutan pada priode berikutnya dengan produk yang berbeda pada daerah yang sama, yaitu Desa Malangke Kecamatan Malangke Kabupaten Luwu Utara.

\section{Kelayakan perguruan Tinggi}

Sekolah Tinggi Ilmu Ekonomi (STIE) Muhammadiyah Palopo merupakan suatu pendidikan tinggi yang aktif dalam melaksanakan program pengabdian masyarakat sebagai salah satu program Tri Dharma Perguruan Tinggi. Kegiatan program pengabdian masyarakat ini dikoordinir dalam satu lembaga yaitu Pusat Penelitian dan Pengabdian pada Mayarakat (P3M) STIE Muhammadiyah Palopo. Lembaga ini telah banyak melakukan program-program pengabdian masyarakat baik berupa fisik maupun non fisik.

Berdasarkan Surat Keputusan Ketua STIE Muhammaduyah Palopo Nomor : 16/KEP/III.3.AU/F/2013, tentang penelitian dan pengabdian.. Salah satu program pengabdian yang dilakukan adalah Kuliah Kerja Nyata (KKN) setiap tahun dengan mewajibkan kepada seluruh mahasiswa tingkat akhir yang telah memenuhi syarat akademik. Kurikulum STIE Muhammadiyah Palopo memasukkan KKN sebagai matakuliah wajib dengan 4 SKS pada mahasiswa tingkat akhir.

Tema KKN yang telah dilaksanakan oleh STIE Muhammadiyah Palopo, adalah peningkatan kesejahteraan ekonomi masyarakat dengan KKN. Untuk mencapai tujuan KKN yang telah dilakukan, STIE Muhammadiyah Palopo melakukan kerjasama dengan pemerintah daerah, Badan Usaha Milik Negara maupun Daerah, serta pelaku-pelaku usaha yang mempunyai kepentingan dengan masyarakat setempat

\section{Simpulan dan Saran}

Dalam pelaksanaan kegiatan KKN-PPM tahun akademik 2018-2019 dilaksanakan di

Desa Malangke Kecamatan Malangke Kabupaten Luwu Utara dimulai sejak tanggal 02 Juli 2018 sampai dengan 02 Agustus 2018, maka dapat disimpulkan :

1) Melalui program KKN-PPM yang dilaksanakan oleh STIE Muhammadiyah Palopo tahun 
akademik 2018-2019, merupakan media untuk memperkenalkan pergguruan tinggi kepada masyarakat, khususnya di Desa Malangke kecamatan malangke Kabupaten Luwu Utara..

2) Melalui program KKN-PPM sebagai media aktualisasi disiplin keilmuan yang dilaksanakan oleh para dosen dengan melibatkan mahasiswa dan masyarakat melalui pengabdaian masyarakat untuk meningkatkan perekonomian masyarakat.

3) Melalui program KKN-PPM terbangunnya sinergitas antara masyarakat, pemerintah, dan perguruan tinggi dalam melaksanakan program-program pemerintah maupun programprogram perguruan tinggi.

Berdasarkan pada uraian diatas, maka yang menjadi saran dalam pelaksanksanaan pengabdian tersebut adalah sebagai berikut :

1) Dalam pelaksanaan kegiatan KKN-PPM yang dilaksanakan di Desa Malangke Kecamatan Malangke Kabupaten Luwu Utara untuk kedepannya masih perlu di tingkatkan, terutama penempatan lokasi KKN-PPM harus disesuaikan dengan program yang di bawah dari kampus. Misalnya program yang di angkat di sektor pertanian (Padi) tapi daerah yang ditempatkan tidak ada sawah, sehingga agak menyulitkan bagi dosen pembimbing lapangan.

2) Pelaksanaan program KKN-PPM untuk kedepannya kalau bisa di tambah alokasi waktunya dan anggaranya, sehingga dalam pelaksanaan program KKN-PPM tersebut, semuanya tutas atau dapat terlaksana sesuai dengan waktu yang diharapkan.

3) Dalam penyusunan jurnal pengabdian ini mungkin masih terdapat kekurangan-kekurangan, tentu saran dan kritik yang sifatnya menyempurnakan kami sangat harapkan.

\section{Ucapan Terima Kasih}

Ucapan terima kasih kepada Lembaga Penelitian dan Pengabdian Masyarakat (LPPM) STIE Muhammadiyah Palopo, prodi Ekonomi Pembangunan, Pemerintah Desa Malangke Kecamatan Malangke dan Kabupaten Luwu Utara yang telah memberikan kesempatan serta memfasilitasi terselenggaranya kegiatan pengabdian pada masyarakat. Demikian, kegiatan dapat berjalan sesuai dengan target waktu yang ditentukan.

\section{Daftar Pustaka}

Panduan Ristek Dikti tentang Pelaksanaan Penelitian dan Pengabdian Pada Masyarakat di Perguruan Tinggi, Edisi XI, Tahun 2017

Zakiul. J, 2014, Indonesia Menghadapi Era Baru Ekonomi Kreatif. (http:/news.indonesiakreatif.net/era-ekonomi-kreatif) 
Jurnal, 2014, Dwi Nur Hijrahan, dkk, Variansi penambahan tepung tapioka sebagai pengganti bleng (boraks) dalam pembuatan kerupuk gender ditinjau dari sifat fisik dan masa simpan, Poltekses Kemenkes, Yokyakarta.

Jurnal Pena Sain, Vol.2 No.2, Okt 2015 ISSN: 2407-2311, Laila Khamsatul Muharrami, Analisis Kualitatif Kandungan Boraks pada Kerupuk Puli di Kecamatan Kamal..Univ.Trumojoyo Madura, Bangkalan

Jurnal Teknologi Proses dan Inovasi, Vo.2 No.1, Juli 2017, Fajar Kurnia Hartati, Analisisi Boraks Secara Cepat, Mudah dan Murah pada Kerupuk, Univ. Dr. Sutomo, Surabaya. https://www.google.co.id/search?q=jurnal+tentang+kerupuk+bleng\&oq=jurnal+tentang+kerupuk +bleng\&aqs=chrome..69i57.16782j0j7\&sourceid $=$ chrome \&ie $=U T F-8$

\section{LAMPIRAN}

\section{Lampiran 1 : Peta Wil. Desa Malangke Kecamatan Malangke Kabupaten Luwu Utara}

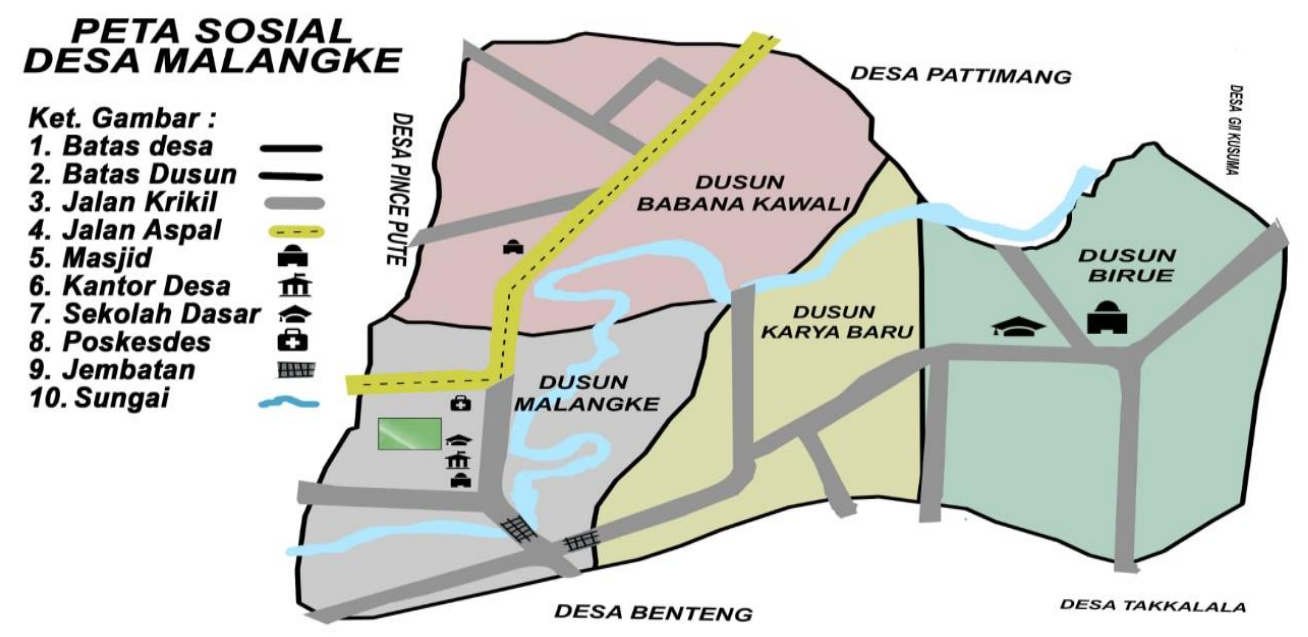

